\title{
The Intermediary Role of Capital Structure and Cash Attitude in the Relationship between Research and Development (R\&D) Capacity and Financial Performance: The Case of Istanbul Manufacturing Industry Enterprises
}

\section{Araştırma ve Geliştirme (AR-GE) Kapasitesi ile Finansal Performans Arasındaki İlişkide Sermaye Yapısı ve Nakit Tutumunun Aracı Rolü: İstanbul İmalat Sanayi İşletmeleri Örneği}

Fahrettin Pala a, ${ }^{\text {, }}$, Aylin Erdoğdu ${ }^{\mathrm{b}}$

${ }^{a}$ Dr. Öğr. Üyesi, Gümüşhane Üniversitesi, Kelkit Aydın Doğan Meslek Yüksekokulu, Muhasebe ve Vergi Bölümü, 29000, Gümüşhane/Türkiye. ORCID: 0000-0001-9565-8638

b Dr. Öğr. Üyesi, İstanbul Arel Üniversitesi, İ.İ.B.F., Bankacılık ve Finans Bölümü, 34537, İstanbul/Türkiye. ORCID: 0000-0001-2345-6789

\section{ART ICLE INFO}

\section{Article history:}

Received: November 1, 2020

Received in revised form: April 1, 2021

Accepted: April 9, 2021

\section{Keywords:}

Cash Attitude

Capital Structure

R\&D Capacity

Financial Performance

\section{MAKALE BİLGISİ}

Makale Geçmişi:

Başvuru tarihi: 1 Kasım 2020

Düzeltme tarihi: 1 Nisan 2021

Kabul tarihi: 9 Nisan 2021

\section{Anahtar Kelimeler:}

Nakit Tutumu

Sermaye Yapısı

AR-GE Kapasitesi

Finansal Performans

\begin{abstract}
A B S T R A C T
The aim of this study is to investigate whether capital structure and cash attitude play an intermediary role in the relationship between research and development (R\&D) capacity and financial performance. The research data are obtained from business managers, who are medium and large scale companies operating in Istanbul and are also an R\&D center, by survey method. Mediator analysis technique is applied to 139 data obtained. Structural equation model was used in the analysis of the data. SmartPLS program was used in the estimation of YEM. Analysis results revealed that R\&D capacity and cash attitude have a direct effect on financial performance, whereas capital structure has no direct effect on financial performance. In addition, the research results supported the intermediary role of cash attitude in the relationship between R\&D capacity and financial performance, while not supporting the intermediary role of capital structure.
\end{abstract}

ÖZ

Çalıșmanın amacı, Araştırma ve Geliştirme (AR-GE) kapasitesi ile finansal performans arasındaki ilişside sermaye yapısı ve nakit tutumunun aracı rolünün olup olmadığının araştırılmasıdır. Araştırma verileri İstanbul'da faaliyet gösteren orta ve büyük ölçekli aynı zamanda AR-GE merkezi olan işletme yöneticilerinden anket yöntemiyle elde edilmiştir. Elde edilen toplam 139 veriye mediatör (aracı) analizi tekniği uygulanmıştır. Verilerin analizinde Yapısal Eşitlik Modeli (YEM) kullanılmıştır. YEM'in tahmininde de SmartPLS programından yararlanılmıştır. Analiz sonuçları, AR-GE kapasitesi ve nakit tutumunun finansal performans üzerinde direkt etkisi olduğunu, sermaye yapısının ise finansal performans üzerinde direkt etkisi olmadığını ortaya koymuştur. Ayrıca araştırma sonuçları AR-GE kapasitesi ile finansal performans arasındaki ilişkide nakit tutumunun aracı rolünü desteklerken, sermaye yapısının aracı rolünü desteklememiştir.

\section{Introduction}

Increasing competition with globalization, rapid changes and developments in technology have led to shortening of products' life in the market. It has become a necessity for businesses that want to grow and / or maintain their market position in an intense competitive environment. While businesses that place innovation at the center of their strategic plans can survive, it is a fact that businesses that are more thrifty towards innovation and cannot give up their traditions are disappearing from the markets. Therefore; innovation is vital to operations.

\footnotetext{
* Sorumlu yazar/Corresponding author.

e-posta: fahrettinpala@gumushane.edu.tr
} 
The prerequisite of innovation, which is of vital importance for businesses, is R\&D. In this direction, enterprises that will innovate should allocate significant funds for their R\&D activities. Because the innovative approaches emerging as a result of R\&D activities are evaluated from an entrepreneur perspective and commercialized (MÜSİAD, 2012: 56). R\&D capacity is seen as one of the activities supporting innovation (Aras et al., 2014: 50). Innovative approaches that emerge as a result of $R \& D$ activities turn into economic and social benefits as long as they are commercialized and help them maximize their profits by creating added value for businesses.

In order for businesses to continue their activities, they must have certain amounts of cash. We can explain the reasons why businesses have cash as follows. First, businesses keep cash in order to be able to perform their daily activities without interruption, which is the transaction motive. Second, they hold cash in order to take advantage of the opportunities that may arise in the market, which is a motive for speculation. Thirdly, they keep cash in case of possible problems in the future, which is a precautionary motive (Türko, 1998: 249 and Barut, 2014: 20). Entrepreneurs' attitudes towards holding cash have a significant impact on the profitability of the business.

In short, capital structure can be defined as the relationship between the debts of businesses and their own resources (Akgüç, 1998: 481). In other words, the composition of firms' resources is called capital structure (Otluoğlu, 2017). When the capital structure is considered broadly, it is defined as "securities of enterprises, bank debts, commercial debts, financial leasing contracts, tax, social insurance and retirement liabilities, deferred compensation of personnel, all other guarantees and liabilities" (Yener, 2002: 5). Businesses need resources to finance these assets in order to invest in their assets. Businesses meet these financing needs from partners, equities provided by partners or foreign resources in the form of borrowing. As it can be understood from the above mentioned, capital structure refers to the distribution of resources used in financing the assets of the enterprises. Covering these resources with equity or foreign resources is an important issue as it creates some cost elements for businesses.

It consists of five sections for the purpose of the study. After explaining the introduction in the first part, the literature review and the hypotheses of the research are explained in the second part. In the third part, the methodology part of the research is explained. In the fourth part, after explaining the analysis and findings of the research, in the fifth part, the study is concluded by making the results and evaluation.

\section{Conceptual Framework}

In this section of the study, theoretical information about the variables within the scope of the research is given.

\subsection{Research and Development (R\&D) Capacity}

A firm's R\&D can be viewed as a set of organic systems on which input-process-output depends. When R\&D resources are used as input, it results in improved performance throughout the transformation process. Therefore, while it is important to invest in $R \& D$ to maximize $R \& D$ performance, it is also extremely important to take advantage of input components through effective and efficient R\&D processes. That is, the company's overall R\&D capabilities should be adequately secured to link R\&D investment to performance (Kim and Choi, 2020: 3).

R\&D capacity can be defined as the ability of a firm to integrate R\&D strategy, project execution, project portfolio management and R\&D expenditures (Yam et al., 2004: 1126). In particular, R\&D capacity can be largely divided into internal and external capabilities. Internal R\&D capability is the use of the firm's resources to develop R\&D internally. Buddha, R\&D intensity, human resources, etc. can be evaluated in terms of. External R\&D capacity can be defined as a formalized connection structure with the external environment to undertake R\&D, such as human and material networks for research and development, strategic alliances. From the perspective of transaction cost theory, the network is considered important for the firm to create a strategy to reduce costs, and from a strategic management theory perspective, it is desirable to focus resources on specific sectors to increase the firm's competitiveness. In other words, a firm's R\&D capacity can be enhanced by combining its internal capabilities with external sources of information (Kim and Choi, 2020: 2-3).

\subsection{Financial Performance}

In general, the concept of performance is an evaluation method made by using efficiency or social orientation criteria in order to determine how well the expectations of the organization are met (Ersar1; 2018: 86). There are many criteria that determine firm performance in the literature. According to Venkatraman and Ramanujam (1986), performance can be measured by financial and nonfinancial (operational) indicators. Financial criteria relate to economic factors (such as return on investment, return on sales and return on equity) such as profitability and sales growth. Operational criteria are; it is related to nonfinancial success factors such as new product development, market share, satisfaction, quality and market efficiency (Zehir et al., 2015: 361).

Financial performance is defined as the evaluation of the extent to which businesses have achieved their goals in a certain period based on financial performance evaluation criteria (Bulut et al., 2009: 517; Ersar1; 2018: 92). Financial performance is the most common type of performance measurement used by businesses to evaluate their performance. Although financial performance has some deficiencies, it is still the most reliable and preferred measurement method due to the quantitative criteria such as equity profitability, sales profitability and economic profitability (Ersar1; 2018: 93).

\subsection{Capital Structure}

Capital structure is the mix of financing resources used by companies in their activities and asset investments. Firms make use of many borrowing instruments such as ordinary stocks, preferred stocks and financial leasing in their financing. However, in theoretical approaches, capital structure components are summarized simply as debt and equity (Akpınar, 2016: 291). 
The concept of capital structure; It was not a subject that was sufficiently emphasized and explored until the "Theory of Unrelatedness" was proposed by Modigliani \& Miller (MM) (1958). However, following this theory of Modigliani \& Miller (MM) (1958), it is one of the most researched and discussed topics in the literature. In the empirical and toric studies available in the literature, there are findings that debt and equity have different cost structures and different effects on firm performance (Akpınar, 2016: 291).

Capital structure theories are examined in two groups as classical and modern capital structure theories. Classical capital structure theories (Net Income, Net Operating Income, Traditional and Modigliani-Miller Theories) attempt to explain the effects of capital structure decisions on the cost of capital and market value. Modern capital structure approaches (Balancing, Financial Hierarchy, Representation Cost, Sign Effect Theories) are theories that have been developed to explain the variables and affect the capital structure decisions of companies. (Karadeniz and Kaplan, 2016: 41).

\subsection{Cash Attitude}

How much cash businesses will keep depends on various factors. Businesses hold cash for three different reasons. These are the transaction motive, the prudence motive and the speculation motive. It is the cash transaction motive that businesses keep in order to continue their assets without disrupting their normal routine operations. In other words, it is the cash kept by the enterprises in order to fulfil their production activities and to meet their other ordinary expenses. The cash it keeps in the face of possible negativities in the future is a prudent motive. It is an impulse to speculate in cash held to generate revenue by taking advantage of unexpected price increases.

If businesses hold too much cash, they incur the cost of holding cash. However, there is a negative effect and a certain cost of not keeping enough cash on hand. In this case, loan facilities may be difficult. The company may have to make all payments in advance. Lenders can increase the interest rate to meet the increasing risks, taking into account the payment difficulties of the firm (Kaya, 2007: 10).

Cash management in businesses is evaluated in different ways within the framework of the classical and modern approach. Models developed within the framework of the classical approach are models that take into account the opportunity cost resulting from cash holding and transaction costs caused by cash shortages in determining the optimum amount of cash. Models developed within the framework of the modern approach determine the level of cash holding in order to increase the market value of the companies. Today, in addition to opportunity and transaction costs, it is argued that agency costs, asymmetric information, financial distress and bankruptcy costs are also effective in determining the level of cash holding. In the literature, the trade-off theory, financial hierarchy and free cash flow theory developed on the basis of these costs are associated with the cash holding level of firms (Kutlu Futuna, 2017: 616).

\section{Literature Review and Research Hypotheses}

When the literature is examined, there are many studies investigating the effect of R\&D investments or investments on the financial performance of companies. From these studies; Aytekin and Özçalık (2018) examined the effect of R\&D expenditures on financial performance by using panel data analysis method, using data between 2011: Q1-2018: Q1 of 7 companies traded in the BIST technology and informatics index. The results of the study revealed that R\&D expenditures have a significant and positive effect on financial performance. Akgün and Akgün (2016) showed that the effect of R\&D expenditures on profitability, using the quarterly data of Aselsan enterprise 2006Q1-2016Q3, They worked with the squares (EKK) method. Consequently, it has been determined that there is a longterm and in the same direction relationship between $R \& D$ expenditures and profitability. Işık et al. (2016) examined the effect of R\&D expenditures on firm profitability and sales by using panel data analysis method using quarterly data of 30 manufacturing industry firms traded in BIST for the period of 2008: Q1-2014: Q4. Eventually, it has been determined that R\&D expenditures have a statistically significant and positive affect on profitability and sales.

Öztürk and Zeren (2015) analyzed the long-term relationship between R\&D expenditures and sales growth data using panel data analysis method, using data between 2007-Q1-2014-Q3. The results show that there is a positive relationship between R\&D expenditures and sales growth. In their study, Uzun Kocamış and Güngör (2014) tested the effect of $R \& D$ expenditures on profitability using the data of 16 companies traded in the BIST technology sector between 2009 and 2013, using regression analysis method. As a result of their studies, they determined that the effect of R\&D expenditures on profitability is positive and significant. Ayaydın and Karaaslan (2014) analyzed the effect of $R \& D$ investments on financial performance using panel data analysis method, using annual data for the period 2008-2013 for 145 manufacturing enterprises registered in BIST. Consequently, the results of the study revealed that the intensity of $R \& D$ affects the positively financial performance.

Freihat and Kanakriyah (2017), using the data of six Jordanian pharmaceutical companies on the Amman stock exchange in Jordan between 2006 and 2015, examined the effect of R\&D expenditures on financial performance using linear regression analysis method. As a result of their studies, they revealed that $R \& D$ expenditures have a significantly and positively affect financial performance. In his study, VanderPal (2015) investigated the effect of R\&D expenditures on corporate financial performance using the data of 103 companies from different sectors registered in the database of Standard \& Poor between 1979 and 2013, using panel data analysis method. Eventually, it has been revealed that $R \& D$ expenditures have a high positive affect on corporate financial performance. In their study, Zhu and Huang (2012) researched the effect of R\&D investments on financial performance by using multiple regression analysis, using the data of 106 companies operating in the Chinese informatics sector between 2007 and 2009. As a result of their studies, they determined that $R \& D$ investments positively and significantly affect financial performance. 
In the empirical studies available in the literature, it was concluded that in general, R\&D expenditures/investments have a significant and positive affect on financial performance. In this framework, the following hypothesis has been developed in line with the main arguments of the theoretical theory and in parallel with the literature.

H1: R\&D capacity has a positive impact on financial performance.

There is a positive relationship between $R \& D$ capacity and financial performance. While there are many theoretical and empirical studies on different areas of cash attitude, there is no study on the relationship between R\&D capacity and cash attitude. In this framework, the following hypothesis has been developed in line with the main arguments of the theoretical theory and in parallel with the literature, by making use of the studies in the literature on different areas of cash attitude.

\section{H2: R\&D capacity has a positive impact on cash attitude.}

When the literature is examined, while there are many theoretical and empirical studies on the effect of capital structure on financial performance, there is no study on the relationship between R\&D capacity and capital structure. In this framework, the following hypothesis has been developed in line with the main arguments of the theoretical theory, in parallel with the literature, by making use of the studies in different areas of the capital structure.

H3: R\&D capacity has a positive impact on capital structure.

In the literature, there are many theoretical and empirical studies about different areas of cash holding of businesses. In almost all of the results of these studies, it has been stated that the effect of holding cash on financial performance is positive. From these studies; Uygurtürk and Vargün (2018) examined the relationship between cash flow and profitability by using multiple regression analysis method, using the data of 10 vehicle industrial enterprises traded on BIST between 2005 and 2015. The results of the study revealed a positive and significant effect of cash flow on profitability for 8 of the firms within the scope of the study, while for 2 of them there was a negative and significant relationship. In their study, Rocca and Cambrea (2018) investigated the effect of cash holding on financial performance using the data of 261 medium and large-scale enterprises operating in Italy between 1980 and 2015, using panel data analysis method. As a result of their studies, they determined that holding cash positively affects financial performance. In their study, Amahalu and Beatrice (2017) analyzed the relationship between cash attitude and financial performance using the multiple regression analysis method, using the data between 2010 and 2015 of 22 insurance companies traded on the Nigerian stock exchange. As a result of their studies, they determined that holding cash has a significant and positive affect on financial performance.

In their study, Topaloğlu and Nur (2016) analyzed the effect of cash conversion cycle on financial performance with a multiple linear regression model, using the data between 2010 and 2014 of 18 companies registered in the BIST corporate governance index. As a results of their studies, they determined that there is a positive relationship between cash conversion time and profitability, and there is no relationship with return on equity. In his study, Demirgüneş (2016) investigated the effect of liquidity (cash) on financial performance by using time series analysis method by using the data of retail companies traded in BIST between 1998.Q1-2015.Q3 periods. As a result of his study, he found that cash attitude affects financial performance positively and significantly. In his study, Onwonga (2016) examined the effect of cash attitude practices on financial performance by using the data of 43 commercial banks operating in Kenya between 2010 and 2014, using regression analysis and ANOVA methods. The results of the study revealed that cash holding activities affirmative and positively affect the financial performance.

Empirical studies in the literature general results that cash attitude has a effects positively on financial performance. In this framework, in line with the basic arguments of the theoretical theory, the following hypothesis has been developed in parallel with the literature.

H4: Cash attitude has a positive impact on financial performance.

When the literature is examined, there are many theoretical and empirical studies on the effect of capital structure on financial performance. There is no consensus in the literature that capital structure has only one effect on financial performance. The results of the studies show that the overall affect is in different directions. From these studies; Y1lmaz (2017) analyzed the effect of capital structure on firm value and financial performance using the data of 60 companies registered in the BIST 100 index between 2000 and 2012. The results of the study revealed that it affects the values of the firms negatively and significantly at the lowest level. Topaloğlu et al. (2006) examined the impact of structure on financial performance using panel regression analysis method, using the data between 2009 and 2015 of 18 companies listed in the BIST 30 index. The results of the study revealed that there is a statistically significant and positive relationship between capital structure and financial performance. In his study, Mutegi (2016) examined the effect of capital structure on financial performance using the data of 47 companies traded on the Nairobi Stock Exchange between 2011 and 2015, using regression analysis. The study results revealed that capital structure has an adverse effect on financial performance. In other words, as the borrowing ratios increase, the financial performance decreases.

Yener and Karakuş (2012) analyzed the capital structure on firm's value using the data of 63 companies registered in the ISE 100 index between 2004 and 2009, panel data analysis method. The results of the study revealed that the capital structure has an effect on the firm value. In his study, Pratheepkanth (2011analyze the effect of capital structure on financial performance capacity, using data from 2005-2009 of some companies traded on the Sri Lanka Colombo stock exchange. The study results revealed that the capital structure affects the financial performance negatively. Birgili and Düzer (2010), using the data of 58 companies traded in the ISE 100 index between 2001 and 2006, examined whether the various financial ratios of the enterprises affect the value of the enterprise by using panel data analysis method. As a result of their studies, they 
determined that the capital structure affects firm value positively and significantly.

In the empirical studies available in the literature, the effect of capital structure on financial performance is generally different. In this context, the following hypotheses have been developed in line with the literature in line with the main arguments of the theoretical theory.

H5: Capital structure has a positive impact on financial performance.

While there are many studies examining the relationship between $R \& D$ capacity and financial performance in the literature, there is no study investigating the intermediary role of cash attitude and capital structure in the relationship between $R \& D$ capacity and financial performance. In this framework, the following hypotheses have been developed in line with the literature in line with the main arguments of the theoretical theory, by making use of other studies on both capital structure and cash attitude.

H6: Cash attitude has an intermediary role between R\&D capacity and financial performance.

H7: Capital structure has an intermediary role between R\&D capacity and financial performance.

\section{Methodology}

\subsection{Purpose of the Research}

To investigate whether the capital structure and cash attitude have a mediator role in the relationship between the R\&D capacities and financial performances of medium and large scale manufacturing industry enterprises operating in Istanbul.

\subsection{Scope of the Research}

139 manufacturing industry enterprises operating in the city of Istanbul, medium and large scale, which are also R\&D centers and whose data can be accessed, were included in the study.

\subsection{Contribution of the Research to the Literature}

Although there are many studies in the literature on the impact of various fields of $R \& D$ activities on financial performance, there are no studies investigating the mediating role of capital structure and cash attitude in the effect of $R \& D$ capacity on financial performance. It is expected that the study will contribute to the literature in this sense by filling this gap. Especially in developing countries carried out this work on Turkey, it is also important.

\subsection{Limitations of the Study}

The study includes evaluating the intermediary role of capital structure and cash attitude in the relationship between R\&D capacity and financial performance in medium and large-scale enterprises operating in the province of Istanbul, as well as an R\&D center. For this evaluation, the survey technique was used as the data collection method in the study, due to its standard data acquisition and its superior data analysis. The unwillingness of business managers to answer survey questions and the difficulties in obtaining proportional data related to financial criteria of businesses constitute the most important constraints of the study.

\subsection{Research Method and Data Set}

In the study, variance-based partial least squares structural equation modeling (PLS-SEM) model, one of the structural equation model methods, was used in the analysis of the data obtained from the questionnaires. The reason for using this model is that the sample size is small for the covariance-based structural equation modeling (CB-SEM) model and the PLS-SEM model may also work in a small sample. In the PLS-SEM model, as in the CB-SEM model, this method was used because it does not consider whether the data has a normal distribution or not.

The universe of the research consists of the managers of medium and large-scale enterprises that are also an R\&D center operating in the Istanbul region. The data were obtained from the Istanbul Chamber of Industry and the Official Website of the Ministry of Industry and Technology, General Directorate of R\&D Incentives. The number of medium and large-scale enterprises registered with the Istanbul chamber of industry is 3631 . The number of enterprises registered to the General Directorate of R\&D Incentives is 352 and the number of medium and largescale enterprises is 179. Managers of 151 of 179 businesses were reached between August 2018 and June 2019 and 139 of them returned. All 139 return questionnaires were included in the scope of the research.

\subsection{Research Model to Test}

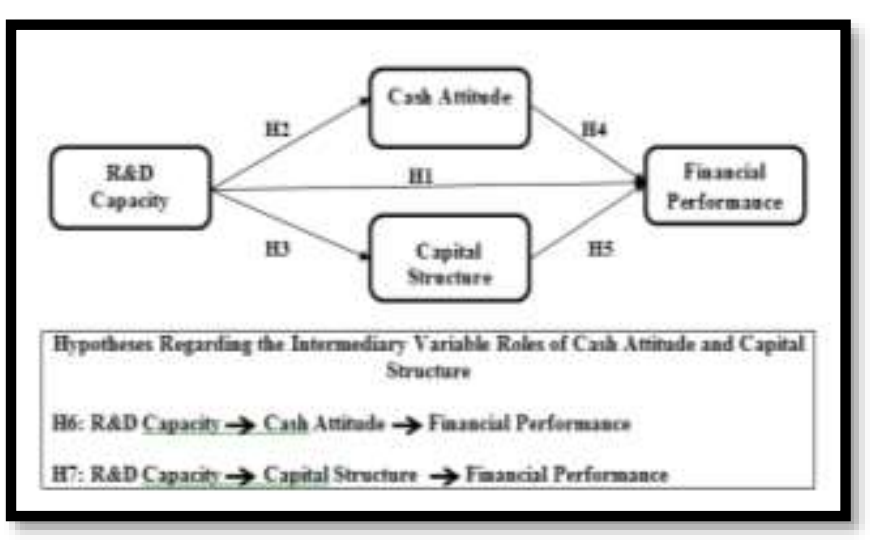

Figure 1. Research Model

\subsection{Findings and Interpretation of the Research}

In this section, after giving descriptive information about the participants, respectively, reliability, validity and confirmatory factor analysis results of the scales are explained. 


\subsubsection{Findings Regarding Demographic Features}

Table 1. General Characteristics of the Participants

\begin{tabular}{|c|c|c|c|}
\hline Variable & Category & $\begin{array}{c}\mathbf{f} \\
(n=139)\end{array}$ & $\%$ \\
\hline \multirow{2}{*}{ Gender } & Female & 56 & 40,8 \\
\hline & Male & 83 & 59,2 \\
\hline \multirow{4}{*}{ Position in the Business } & $\begin{array}{l}\text { Owner / } \\
\text { Partner }\end{array}$ & 10 & 7,2 \\
\hline & $\begin{array}{l}\text { President } \\
(\mathrm{CEO} / \mathrm{COO})\end{array}$ & 12 & 8,6 \\
\hline & $\begin{array}{l}\text { Department } \\
\text { Manager }\end{array}$ & 95 & 68,4 \\
\hline & Other & 22 & 15,8 \\
\hline \multirow{5}{*}{ Firm Age } & $\begin{array}{l}1-5 \text { Years } \\
\text { Old }\end{array}$ & 4 & 2,9 \\
\hline & $\begin{array}{l}\text { 6-10 Years } \\
\text { Old }\end{array}$ & 11 & 7,9 \\
\hline & $\begin{array}{l}\text { 11-20 Years } \\
\text { Old }\end{array}$ & 21 & 15,1 \\
\hline & $\begin{array}{l}21-50 \text { Years } \\
\text { Old }\end{array}$ & 79 & 56,8 \\
\hline & 51 and Over & 24 & 17,3 \\
\hline \multirow{5}{*}{ Number of Employees } & 50-100 & 14 & 10 \\
\hline & $101-150$ & 21 & 15,1 \\
\hline & $151-200$ & 23 & 16,6 \\
\hline & $201-250$ & 30 & 21,6 \\
\hline & $\begin{array}{l}251 \text { and } \\
\text { Over }\end{array}$ & 51 & 36,7 \\
\hline
\end{tabular}

When Table 1 is examined; $40.8 \%$ (56) of those participating in the research are women and 59.2\% (83) are men. This situation shows that the majority of managers are men. When looking at the positions of the participants in the business, $7.2 \%$ (10) are business owners or partners, $8.6 \%$ (12) are President (CEO / COO), 68.4\% (95) are R\&D department managers and $15.8 \%$ (22) of them are people who work in $\mathrm{R} \& \mathrm{D}$ departments in chief positions. Another demographic feature is the age of companies. $56.8 \%$ of the companies within the scope of the research are experienced enterprises between the ages of 21 and 50 . Looking at the number of employees of the companies participating in the survey, it is seen that $36.7 \%$ of them are large enterprises with 251 and more employees.

\subsubsection{Reliability and Validity Test of the Measurement Model}

Questions about the R\&D capacity variable among the scales included in the research were given to Oura et al. (2016) developed on the basis of the scale. The 4 questions in the scale were adapted to Turkish, taking into account the views of the academicians. Questions related to the financial performance scale are "Return on Investment (Profit / Total Assets)", "Economic Profitability (Profit Before Interest and Tax / Total Assets)", "Profit on Sales (Profit / Net Sales)" and It was measured as "Equity Profitability (Profit / Equity)". Capital structure has been measured as the ratio of "Long Term Liabilities / Total Assets", "Short Term Liabilities / Total Assets" and "Total Foreign Resources / Equity", which are frequently used in the literature. Cash attitude has been measured with "Liquid Assets / Total Assets", "Liquid Assets / With Net Sales" and "Liquid Assets / Fixed Assets" ratios, which are frequently used in the literature. Questions for all variables are given in Annex-1.

Reliability analysis is an analysis that needs to be done in terms of expressing the consistency of each question in the questionnaires with each other and to what extent the scale used reflects the problem. Accordingly, the reliability of the scales within the scope of the research was measured with Cronbach Alpha and Composite Reliability values.

Validity analysis is an analysis required to determine the basic factors of the scales within the scope of the research and to test the validity of the scale. Accordingly, the validity of the scales within the scope of the research was measured by the validity of dissociation and convergence. Fornell-Larcker and Heterotrait-Monotrait Ratio (HTMT) for factor loadings and Average Variance Extracted / AVE) convergence validity, and for decomposition validity.

For this reason, in terms of the continuation of the study, the reliability and dissociation validity tests of the variables of the study are given in Table 2, and the dissociation validity tests are given in Table 3 and Table 4.

Table 2. Reliability and Validity Results of the Research Model

\begin{tabular}{|c|c|c|c|c|c|}
\hline Variables & 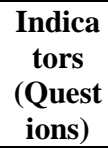 & $\begin{array}{c}\text { Indic } \\
\text { ator } \\
\text { Load } \\
\mathbf{s} \\
\end{array}$ & $\begin{array}{c}\text { Cron } \\
\text { bach } \\
\text { Alpha } \\
(\alpha) \\
\end{array}$ & $\begin{array}{c}\text { Comp } \\
\text { osite } \\
\text { Reliab } \\
\text { ility } \\
\end{array}$ & $\begin{array}{c}\text { Average } \\
\text { Variance } \\
\text { Extracted } \\
\text { (AVE) }\end{array}$ \\
\hline \multirow{4}{*}{$\begin{array}{l}\text { R\&D } \\
\text { Capacity }\end{array}$} & RDC1 &, 822 & \multirow{4}{*}{,762 } & \multirow{4}{*}{847} & \multirow{4}{*}{, 585} \\
\hline & RDC2 & ,873 & & & \\
\hline & RDC3 & ,751 & & & \\
\hline & RDC4 &, 582 & & & \\
\hline \multirow{4}{*}{$\begin{array}{l}\text { Financial } \\
\text { Performance }\end{array}$} & FP1 & ,852 & \multirow{4}{*}{,922 } & \multirow{4}{*}{,945 } & \multirow{4}{*}{, 811} \\
\hline & FP2 & ,926 & & & \\
\hline & FP3 & ,924 & & & \\
\hline & FP4 & 899 & & & \\
\hline \multirow{3}{*}{ Cash Attitude } & CA1 & ,951 & \multirow{3}{*}{,903 } & \multirow{3}{*}{,939 } & \multirow{3}{*}{,838 } \\
\hline & CA2 & ,939 & & & \\
\hline & CA3 & 852 & & & \\
\hline \multirow{3}{*}{$\begin{array}{l}\text { Capital } \\
\text { Structure }\end{array}$} & CS1 & ,852 & \multirow{3}{*}{,888 } & \multirow{3}{*}{,931 } & \multirow{3}{*}{,818 } \\
\hline & $\mathrm{CS} 2$ & ,931 & & & \\
\hline & $\mathrm{CS} 3$ & ,928 & & & \\
\hline
\end{tabular}

When Table 2 is analyzed, both Cronbach's Alpha and Composite Reliability values are given for the reliability of the variables in the study. The reason why these values are given together is that the Cronbach Alpha value calculates the reliability less than it should be and accepts the reliability between the indicators as equal. When the literature is examined, as Nunnally (1967) stated, in order for the scale to be reliable, the Cronbach Alpha value must be equal to or above 0,70 . When Table 2 is analyze, it is seen that the Cronbach Alpha value of all variables is above 0.70. Likewise, when the literature was examined, it was stated that the Composite Reliability value should be between 0,70 and 0,95 (Hair et al., 2014: 112; Sartestedt et al., 2017: 16). Likewise, Composite Reliability values are above the threshold values expressed in the literature. As a result, since both the Cronbach's Alpha value and the Composite Reliability value are above the critical values stated in the literature, it can be said that the variables within the scope of the research are reliable.

Looking at Table 2, it is seen that there are four latent variables in total within the scope of the research. Among 
these variables, it is seen that the load ranges of the indicator values for R\&D capacity take different values between 0,582 and 0,873 for financial performance between 0,852 and 0,926 for cash attitude between 0,852 and 0,951 and for capital structure between 0,852 and ,931. Hair et al. (2014) As stated by, the importance of indicator values in defining the variable should be taken into account, instead of directly discarding those between 0,40 and 0,70 . In this direction, only the factor load of the RDC4 indicator is among the specified critical values $(0,582)$, and this was not excluded from the scope of the study due to its importance. This situation shows that the scales of the variables are valid in terms of factor loadings. In the literature, the acceptable threshold value for AVE value is expressed as 0,50 or above (Sartestedt et al., 2017: 17). When the AVE values are examined, it is seen that is above the critical value of 0,50 . This situation shows that the scales belonging to the variables within the scope of the research are valid.

Another value to be considered for the validity of the variables within the scope of the study is the correlation values between Fornell-Larcker values and the latent variables themselves. Both of the values belonging to these criteria are given in Table 3 .

Table 3. Fornell-Larcker and Correlation Values for the Measurement Model

\begin{tabular}{lllll}
\hline Variables & $\begin{array}{l}\text { R\&D } \\
\text { Capaci } \\
\text { ty }\end{array}$ & $\begin{array}{l}\text { Financial } \\
\text { Performa } \\
\text { nce }\end{array}$ & $\begin{array}{l}\text { Cash } \\
\text { Attitu } \\
\text { de }\end{array}$ & $\begin{array}{l}\text { Capital } \\
\text { Structu } \\
\text { re }\end{array}$ \\
\hline $\begin{array}{l}\text { R\&D Capacity } \\
\begin{array}{l}\text { Financial } \\
\text { Performance }\end{array}\end{array}$ &, 765 & & & \\
Cash Attitude &, 356 & $\mathbf{, 9 0 1}$ & & \\
Capital Structure &, 309 &, 471 & $\mathbf{, 9 1 5}$ & \\
\hline
\end{tabular}

According to the Fornell-Larcker criterion, the square root of the explained mean variance (AVE) of each variable should be greater than the correlation of the variable with other variables (Doğan, 2019: 46). In other words, the values given in bold text are the square root of the AVE value of the relevant variable, and each value must be higher than the correlation values in the column to which it is attached. When Table 3 is analyzed, it is seen that the R\&D capacity variable is 0,765 the financial performance variable is 0,901 , the cash attitude variable is 0,915 and the capital structure variable is 0,904 . Likewise, when the correlation values are examined, it is seen that it takes values varying between 0,236 and 0,915 . This situation indicates that the scales belonging to the variables within the scope of the research are valid.

Table 4. Heterotrait-Monotrait Ratio (HTMT) for the Measurement Model

\begin{tabular}{lllll}
\hline Variables & R\&D & Financial & Cash & Capital \\
& $\begin{array}{l}\text { Capaci } \\
\text { ty }\end{array}$ & $\begin{array}{l}\text { Performa } \\
\text { nce }\end{array}$ & $\begin{array}{l}\text { Attitu } \\
\text { de }\end{array}$ & $\begin{array}{l}\text { Structu } \\
\text { re }\end{array}$ \\
\hline
\end{tabular}

\begin{tabular}{llll}
\hline R\&D Capacity & & & \\
$\begin{array}{l}\text { Financial } \\
\text { Performance }\end{array}$ & 0,393 & & \\
Cash Attitude & 0,353 & 0,501 & \\
Capital Structure & 0,351 & 0,292 & 0,246 \\
\hline
\end{tabular}

HTMT expresses the ratio of the average correlations of the indicators of all variables in the model to the geometric mean of the correlations of the indicators belonging to the same variable (Doğan, 2019: 47). The exact threshold level of HTMT is a controversial issue, with some authors suggesting a threshold of 0.85 (Clark and Watson, 1995) and some suggesting a threshold value of 0.90 (Gold et al. 2001; Teo et al. 2008; Henseler et al.2015). When Table 4 is examined, it is seen that all values are lower than the threshold values (0.85-0.90) expressed in the literature. This shows that the scale of variables included in the research is valid.

\subsubsection{Linearity, Prediction Power and Effect Size Tests}

The variance increasing factor (VIF) method was used to test whether there is a multi-linearity problem among the variables included in the study, and the VIF values are given in Table 7. Similarly, the predictive power $\left(\mathrm{Q}^{2}\right)$ and effect size $\left(\mathrm{f}^{2}\right)$ and $\mathrm{R}^{2}$ test results are also given in Table 7.

Table 5. Variance Increasing Factor (VIF) Test Results

\begin{tabular}{llclc}
\hline Variables & $\begin{array}{l}\text { R\&D } \\
\text { Capaci } \\
\text { ty }\end{array}$ & $\begin{array}{l}\text { Financial } \\
\text { Performa } \\
\text { nce }\end{array}$ & $\begin{array}{l}\text { Cash } \\
\text { Attitu } \\
\text { de }\end{array}$ & $\begin{array}{l}\text { Capital } \\
\text { Structu } \\
\text { re }\end{array}$ \\
\hline R\&D Capacity & & 1,191 & 1,000 & 1,000 \\
$\begin{array}{l}\text { Financial } \\
\text { Performance }\end{array}$ & & & \\
Cash Attitude & 1,141 & & \\
Capital Structure & 1,131 & \\
\hline \hline
\end{tabular}

Predictive Power Analysis ( $\left.\mathbf{Q}^{2}\right)$ Results

\begin{tabular}{|c|c|c|c|}
\hline & SSO & SSE & $\begin{array}{l}Q^{2} \quad(=1- \\
\text { SSE/SS } \\
\text { O) }\end{array}$ \\
\hline R\&D Capacity & 372,000 & 372,00 & \\
\hline $\begin{array}{l}\text { Financial } \\
\text { Performance }\end{array}$ & 372,000 & 297,55 & 0,200 \\
\hline Cash Attitude & 279,000 & 258,71 & 0,073 \\
\hline Capital Structure & 279,000 & 260,38 & 0,067 \\
\hline
\end{tabular}

Effect Size ( $\left.\mathbf{f}^{2}\right)$ Results

\begin{tabular}{lllll} 
& R\&D & FP & CA & CS \\
\hline R\&D Capacity & & 0,047 & 0,115 & 0,105 \\
$\begin{array}{l}\text { Financial } \\
\text { Performance }\end{array}$ & & & \\
Cash Attitude & 0,176 & & \\
Capital Structure & 0,014 & \\
\hline \hline
\end{tabular}

$\mathbf{R}^{2}$ Results 


\begin{tabular}{lll}
\hline Performance & & \\
Cash Attitude & 0,103 & 0,093 \\
Capital Structure & 0,095 & 0,085 \\
\hline
\end{tabular}

When Table 7 is examined, it can be said that there is no linearity problem among the variables, since all the variance increasing factor values of the indicators are smaller than the critical threshold value of 5 (Hair et al., 2014) stated in the literature.

The prediction power $\left(\mathrm{Q}^{2}\right)$ value is the value that shows how well the correlation coefficients can predict an observed dependent variable (Doğan, 2019: 95). According to Hair et al. (2014), in the evaluation to be made for $\mathrm{Q}^{2}$ values, it is evaluated as 0.02 low, 0.15 medium and 0.35 high. When Table 7 is examined, it is seen that the $\mathrm{Q}^{2}$ value of the financial performance variable, which is the dependent variable, is 0.200 . This situation shows that the research model has the power to predict the financial performance variable at a medium level. Similarly, one of the intermediary variables, the $\mathrm{Q}^{2}$ value of the cash attitude is 0.073 and the $\mathrm{Q}^{2}$ value of the capital structure is 0.067 . This shows that the research model has a low predictive power of the mediating variables.

The effect size is determined by $\mathrm{f}^{2}$ values. The value of $\mathrm{f}^{2}$ is calculated for each independent variable and shows the share of the independent variable in the dependent variable explanation rate (Doğan, 2019: 51). The evaluation of the $\mathrm{f}^{2}$ value is considered to be 0.02 low, 0.15 medium and 0.35 high (Cohen, 1988; Doğan, 2019). When the $\mathrm{f}^{2}$ values of the model given in Table 7 are examined, it is seen that the independent variable explains the dependent variable at a low level with 0.047 . Similarly, the intermediary of the independent variable explains the cash attitude of the variables at a low level of 0.115 and the capital structure at 0.105 . It is seen that the cash attitude explains the financial performance at a medium level with 0.176 . However, as stated by Sarstedt et al. (2017), the capital structure is under 0.02 , so no effect can be mentioned.

$\mathrm{R}^{2}$ value is the value indicating what percentage of the dependent variable the independent variable explains. If this value is 0.25 , it is considered weak, if it is 0.50 , it is considered medium, and if it is 0.75 , it is considered strong (Henseler et al., 2009; Hair et al., 2011). When the $\mathrm{R}^{2}$ values of the model given in Table 7 are examined, it is seen that the financial performance is $27.9 \%$, the cash attitude is $10.3 \%$ and the capital structure is $9.5 \%$. These findings show that the dependent variable and mediator variables have a low level of explanation because they are below $50 \%$. The adjusted value of $\mathrm{R}^{2}$ will tend to increase the value of $\mathrm{R}^{2}$ even if each independent variable to be added to the model has a low correlation with the dependent variable. $\mathrm{R}^{2}$ adjusted values are also used to avoid such deviations (Garson, 2016, 82).3.7.4.

\subsubsection{Testing Hypotheses}

There are two basic approaches to statistically proving the mediation effect. It is the causality approach and contemporary approach of Baron and Kenny. Baron and Kenny's causality approach is a long-used and highly popular approach. However, the contemporary approach put forward in recent years has brought significant criticisms to the traditional approach (Muller et al., 2005; Preacher et al., 2007; Hayes 2018; Gürbüz, 2019). If Baron and Kenny's causality approach is supported by three different hypotheses (hypotheses regarding the $a, b$ and $c$ pathway), it can be decided whether the mediation variable is present or not. However, this approach is criticized by contemporary approaches. According to contemporary approaches', the primary focus in mediation model analyses is the calculation of indirect impact values and making inferences from the calculated values. Indirect effect according to this approach; The effect of the predictor variable $(\mathrm{X})$ on the mediating variable $(\mathrm{M})$ is the product of the path (a) of the mediating variable (M) versus the effect of the intermediary variable (M) on the outcome variable (Y) (b). According to the modern approach, mediation is verified if (a.b) is significant as a result of the bootstrap test in the intermediary impact model (Gürbüz, 2019: 54). In this direction, the modern approach method (Gürbüz et al., 2018; Gürbüz, 2019), which provides more valid and reliable results for the analysis of models, was used in the study.

The SmartPLS3 program was used to test the hypotheses. Outputs of the structural model obtained as a result of the analysis are given in Figure 2.

Figure 2.PSL-SEM structural equation model diagram for the scale of the intermediary role of capital structure and cash attitude in the relationship between R\&D capacity and financial performance (Path analysis).

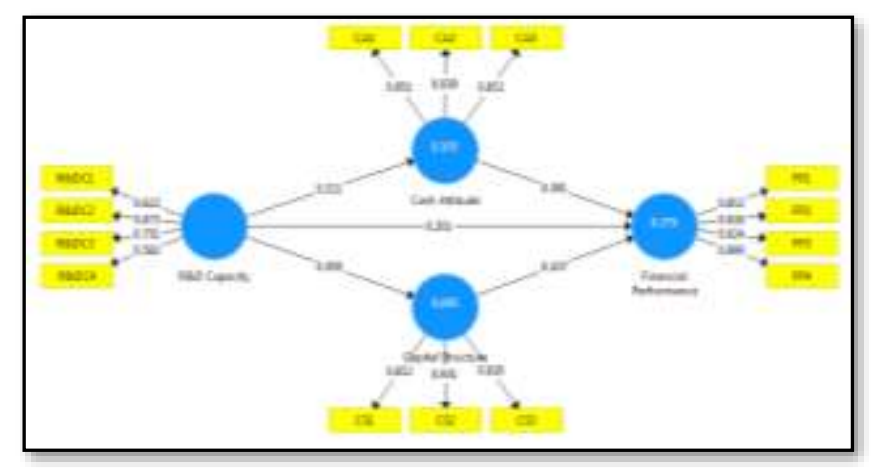

Figure 2. PSL-SEM Diagram

PLS structural equation model uses bootstrapping method in terms of statistical inferences. The Bootstrapping method repeats the sample by pulling random data (n) times from the data set, thus increasing the sample and predicting the standard error better (Varian, 2005, Sözüer, 2016). In order to predict the standard error more accurately, the resampling was performed with 5000 (Hair vd. 2014) derivative samples and the analysis results are given in Table 6. 
Table 6. Path Coefficients T-Statistics Values of the Model

\begin{tabular}{|c|c|c|c|c|c|}
\hline Variables & $\begin{array}{l}\text { Origin } \\
\text { al } \\
\text { Sampl } \\
\text { e }\end{array}$ & $\begin{array}{c}\text { Sampl } \\
\text { e } \\
\text { Mean }\end{array}$ & $\begin{array}{l}\text { Standa } \\
\text { rd } \\
\text { Deviati } \\
\text { on }\end{array}$ & $\begin{array}{c} \\
\text { Statisti } \\
\text { cal } \\
\text { Value } \\
\end{array}$ & $\begin{array}{c}\mathbf{P} \\
\text { Value }\end{array}$ \\
\hline $\begin{array}{l}\text { R\&D } \rightarrow \\
\text { FP }\end{array}$ & ,201 & ,202 & ,089 & 2,257 &, $024 * *$ \\
\hline $\begin{array}{l}\mathrm{R} \& \mathrm{D} \rightarrow \\
\mathrm{CA}\end{array}$ &, 321 & ,332 & ,099 & 3,238 & ,001* \\
\hline $\begin{array}{l}\mathrm{R \& D} \rightarrow \\
\mathrm{CS}\end{array}$ & ,309 & ,320 & ,093 & 3,331 & ,001* \\
\hline $\begin{array}{l}\mathrm{CA} \rightarrow \\
\mathrm{FP}\end{array}$ & ,381 & ,389 & ,089 & 4,290 &, $000 *$ \\
\hline $\begin{array}{l}\mathrm{CS} \rightarrow \\
\mathrm{FP}\end{array}$ & , 107 & , 100 & ,114 & 0,939 & ,348 \\
\hline
\end{tabular}

Note: $(*, * *)$ indicates that they are significant at $1 \%$ and $5 \%$ significance level.

When Table 6 is analyzed, it is seen that R\&D capacity affects financial performance positively $(\mathrm{t}=2,257)$ and significantly $(p=0,024)$. When the $t$ value of the relationship between $R \& D$ capacity and financial performance is examined, it is seen that this value is greater than the critical threshold value of 1,96 stated in the literature. This indicates that the impact of $\mathrm{R} \& \mathrm{D}$ capacity on financial performance is significant at the 0,05 significance level. Among the previously created hypotheses in this direction;

H1: The hypothesis that R\&D capacity has a positive impact on financial performance is supported.

When Table 6 is examined, it is seen that there is a positive $(t=3,238)$ and significant $(p=0,001)$ relationship between $R \& D$ capacity and cash attitude. When the $t$ value of the relationship between $R \& D$ capacity and cash attitude is examined, it is seen that this value is greater than the 2,58 critical threshold value expressed in the literature. This situation indicates that the effect of $R \& D$ capacity on cash attitude is significant at 0,01 level. Among the previously created hypotheses in this direction;

$\mathrm{H} 2$ : The hypothesis that R\&D capacity has a positive impact on cash attitude is supported.

When Table 6 is analyzed, it is seen that there is a positive $(t=3.331)$ and significant $(p=0,001)$ relationship between $\mathrm{R} \& \mathrm{D}$ capacity and capital structure. When the t-value of the relationship between $R \& D$ capacity and capital structure is examined, it is seen that this value is greater than the 2,58 critical threshold value stated in the literature. This indicates that the effect of $R \& D$ capacity on capital structure is significant at the 0,01 level. Among the previously created hypotheses in this direction;

H3: The hypothesis that R\&D capacity has a positive impact on capital structure is supported.

When Table 6 is analyzed, it is seen that there is a positive $(\mathrm{t}=4,290)$ and significant $(\mathrm{p}=0,000)$ relationship between cash attitude and financial performance. When the $t$-value of the relationship between cash attitude and financial performance is examined, it is seen that this value is greater than the 2,25 critical threshold value expressed in the literature. This situation shows that the effect of cash attitude on financial performance is significant at 0,01 level of significance. Among the previously created hypotheses in this direction;
H4: The hypothesis that cash attitude has a positive impact on financial performance is supported.

When Table 6 is analyzed, no significant relationship ( $\mathrm{t}=$ $0,939, \mathrm{p}=0,348$ ) between capital structure and financial performance was found. When the $t$-value of the relationship between capital structure and financial performance is examined, this value is lower than the 1,65 critical threshold value stated in the literature indicates that there is no significant relationship between these two variables. Among the previously created hypotheses in this direction;

H5: The hypothesis that capital structure has a positive impact on financial performance is not supported.

Table 7. Indirect Effects of the Model (Indirect Effects) Path Coefficients T-Statistical Values

\begin{tabular}{lccccc}
\hline Variables & $\begin{array}{c}\text { Origi } \\
\text { nal } \\
\text { Samp } \\
\text { le }\end{array}$ & $\begin{array}{c}\text { Samp } \\
\text { Mean } \\
\text { Mean }\end{array}$ & $\begin{array}{c}\text { Stand } \\
\text { ard } \\
\text { Deviat } \\
\text { ion }\end{array}$ & $\begin{array}{c}\text { Statist } \\
\text { ical } \\
\text { Value }\end{array}$ & $\begin{array}{c}\mathbf{P} \\
\text { Value }\end{array}$ \\
\hline $\begin{array}{l}\text { R\&D } \rightarrow \text { CA } \rightarrow \\
\text { FP }\end{array}$ &, 122 &, 130 &, 052 & 2,359 &, $\mathbf{0 1 8 * *}$ \\
\hline $\begin{array}{l}\text { R\&D } \rightarrow \text { CS } \rightarrow \\
\text { FP }\end{array}$ &, 033 &, 034 &, 041 & 0,801 &, 423 \\
\hline
\end{tabular}

Note: $(* *)$ indicates significant at $5 \%$ significance level

When the $t$ value $(t=2,359)$ regarding the role of cash attitude tool (mediator) in the relationship between $\mathrm{R} \& \mathrm{D}$ capacity and financial performance given in Table 7 is examined, it is seen that this value is greater than the critical threshold value of 1.96 stated in the literature. This indicates that cash attitude has a mediator role in the relationship between $R \& D$ capacity and financial performance. It shows that the effect of $R \& D$ capacity on financial performance through cash attitude is significant at 0.05 significance level. In this direction, one of the basic hypotheses created before;

H6: The hypothesis that cash attitude has a mediating role between R\&D capacity and financial performance is supported.

Likewise, when Table 7 is analyzed, when the $\mathrm{t}$ value $(\mathrm{t}=$ 0.801 ) regarding the intermediary role of the R\&D capacity and capital structure is examined, it is seen that this value is lower than the 1.96 critical threshold value stated in the literature. This situation shows that the capital structure does not have an intermediary role in the relationship between $R \& D$ capacity and financial performance. It shows that the effect of $R \& D$ capacity on financial performance through capital structure is not significant at 0,05 significance level. In this direction, one of the basic hypotheses created before;

H7: The hypothesis that capital structure has an intermediary role between $R \& D$ capacity and financial performance is not supported. 
Table 8. Hypothesis Test Results

\begin{tabular}{|c|c|c|c|c|c|}
\hline $\begin{array}{l}\text { Relationship } \\
\text { s }\end{array}$ & & Findings & & $\begin{array}{c}\text { Hypot } \\
\text { hesis }\end{array}$ & $\begin{array}{l}\text { Conclus } \\
\text { on }\end{array}$ \\
\hline $\begin{array}{l}\text { R\&D } \rightarrow \\
\text { FP }\end{array}$ & $\beta=, 201$ & $t=2,257$ & $\mathrm{p}=, 024$ & H1 & $\begin{array}{c}\text { Support } \\
\text { ed }\end{array}$ \\
\hline $\begin{array}{l}\mathrm{R} \& \mathrm{D} \rightarrow \\
\mathrm{CA}\end{array}$ & $\beta=, 321$ & $\mathrm{t}=3,238$ & $\mathrm{p}=, 001$ & $\mathrm{H} 2$ & $\begin{array}{l}\text { Support } \\
\text { ed }\end{array}$ \\
\hline $\begin{array}{l}\mathrm{R} \& \mathrm{D} \rightarrow \\
\mathrm{CS}\end{array}$ & $\beta=, 309$ & $t=3,331$ & $\mathrm{p}=, 001$ & $\mathrm{H} 3$ & $\begin{array}{l}\text { Support } \\
\text { ed }\end{array}$ \\
\hline $\mathrm{CA} \rightarrow \mathrm{FP}$ & $\beta=, 381$ & $\mathrm{t}=4,290$ & $\mathrm{p}=, 000$ & $\mathrm{H} 4$ & $\begin{array}{c}\text { Support } \\
\text { ed }\end{array}$ \\
\hline $\mathrm{CS} \rightarrow \mathrm{FP}$ & $\beta=, 107$ & $\mathrm{t}=0,939$ & $\mathrm{p}=, 348$ & H5 & $\begin{array}{c}\text { Not } \\
\text { supporte } \\
\mathrm{d}\end{array}$ \\
\hline $\begin{array}{l}\mathrm{R} \& \mathrm{D} \rightarrow \mathrm{F} \\
\mathrm{CA} \rightarrow \mathrm{FP}\end{array}$ & $\beta=, 122$ & $t=2,359$ & $\mathrm{p}=, 018$ & H6 & $\begin{array}{c}\text { Support } \\
\text { ed }\end{array}$ \\
\hline $\begin{array}{l}\mathrm{R} \& \mathrm{D} \rightarrow \\
\mathrm{CS} \rightarrow \mathrm{FP}\end{array}$ & $\beta=, 033$ & $\mathrm{t}=0,801$ & $\mathrm{p}=, 423$ & $\mathrm{H} 7$ & $\begin{array}{c}\text { Not } \\
\text { supporte } \\
\mathrm{d}\end{array}$ \\
\hline
\end{tabular}

In Table 8, the hypothesis test results of the variables within the scope of the research are given in summary. When Table 8 is examined, it is seen that other hypotheses are supported, except for the hypothesis of the relationship between capital structure and financial performance (H5) and the hypothesis of the intermediary role of capital structure (H7) in the relationship between $R \& D$ capacity and financial performance.

\section{Conclusion and Evolution}

The aim of the study is to empirically examine whether cash attitude and capital structure have an intermediary role in the relationship between $R \& D$ capacity and financial performance. In line with this purpose, the universe of the study consists of medium and large-scale manufacturing industry enterprises registered to the General Directorate of R\&D Incentives of the Ministry of Industry and Technology, operating in the Istanbul region. The survey technique is used as the data collection method in the study, due to its standard data acquisition and its superior data analysis. From 179 enterprises register to the General Directorate of R\&D Incentives, 151 business managers are reached, and 139 questionnaires from them are included in the scope of the research.

Variance-based PLS-SEM model, one of the structural equation model methods, is used in the analysis of the data obtained in the study. In the study, firstly, the reliability and validity analyzes of the variables are made and after it is determined that the variables provided the reliability and validity, the hypotheses formed in line with the basic arguments of the theoretical theory are started to be tested in parallel with the literature. In testing the hypotheses, the SmartPLS3 program is used to test the significance of the PLS path coefficients. For this, t-statistics values are calculated by taking 5000 sub-samples from among those included in sampling with bootstrapping.

According to the analysis results, it has been determined that the R\&D capacity has a direct effect on all other variables within the scope of the research and the results are given in Table 4. The mediating role of cash attitude between R\&D capacity and financial performance, which is one of the main hypotheses of the study, is found to be statistically significant $(\mathrm{p}=0,018)$ and positive $(\mathrm{t}=2.359)$, and the H6 basic hypothesis is supported as expected. However, the hypothesis that capital structure has an intermediary role between $R \& D$ capacity and financial performance, which is one of the main hypotheses of the research, is not supported. When the $t$ value $(t=0.801)$ regarding the intermediary (mediator) role of the $R \& D$ capacity and capital structure is examined, it is seen that this value is lower than the critical threshold value of 1.96 stated in the literature. This situation shows that the capital structure does not have an intermediary role in the relationship between $\mathrm{R} \& \mathrm{D}$ capacity and financial performance. In addition, the PLS algorithm was run to test whether there is a multi-linearity problem among the variables within the scope of the study and it is determined that there is no linearity problem between the variables.

Although there are many theoretical and empirical studies in the literature on the impact of various fields of $R \& D$ activities on financial performance, the fact that there are no studies investigating the intermediary role of cash attitude and capital structure in the effect of R\&D capacity on financial performance is a unique indicates that it is working. Likewise, developing the work to be done in Turkey also poses a special importance. Since the study is an original study, it is thought to be important in terms of guiding future studies. In this context, the following suggestions can be given to researchers who will conduct research;

i. Since the research has been applied to medium and largescale manufacturing enterprises operating in the Istanbul region, it is recommended to apply the study in different regions or provinces in order to generalize the results of the study.

ii. It is recommended to apply the research in different sectors.

iii. The research has been carried out on medium and largescale business managers, and it is recommended to conduct the research on Small and medium-sized enterprises (SMEs.)

iv.In order for the research to be universal, it is recommended to compare the development level with different countries.

v. It is recommended to include other variables (such as the moderator effects of environmental factors) so that the research can be evaluated more comprehensively.

\section{References}

Akgüç, Ö. (1998), Financial Management. 7. Edition. Istanbul: Avc1ol Publishing.

Akgün, A., \& Akgün, Ö. (2016). The Effect of R\&D Expenditures on Profitability in Enterprises: The Case of Aselsan. Selçuk University Journal of Social and Technical Researches, 12: 1-12.

Akpinar, O. (2016). The Impact of Capital Structure on Firm Performance: An Application on Borsa Istanbul. 
Kastamonu University Journal of the Faculty of Economics and Administrative Sciences, 11, 290-302.

Amahalu, N.N., \& Beatrice, E. (2017). Effect of Cash Holding on Financial Performance of Selected Quoted Insurance Firms in Nigeria, Journal of Marketing Management and Consumer Behavior, 2(1): 90-112.

Aras, G., Tezcan, N., Kutlu Furtuna, Ö., \& Aybars, A. (2014). Strategic Analysis of $R \& D$ and Innovation Performance of Companies, Istanbul Chamber of Commerce, Publication No: 2014-10.

Ayaydın, H., \& Karaaslan, İ. (2014). The Effect of Research and Development Investment on Firms' Financial Performance: Evidence from Manufacturing Firms in Turkey. The Journal of Knowledge Economy \& Knowledge Management, IX(II): 43-59.

Aytekin, S., \& Özçalık, S.G. (2018). Relationship between r\&d expenditure and financial performance on technology and information technology indices firms in Borsa Istanbul. Anemon Journal of Social Sciences of Mus Alparslan University, 6(ICEESS'18): 67-73.

Barut, A. (2014), Cash Management in businesses and an application in Kars province. Atatürk University Institute of Social Sciences, Master Thesis, Erzurum.

Birgili, E., \& Düzer, M. (2010). The relationship between the rates which are used in financial analysis and firm value an application in Istanbul stock exchange. The Journal of Accounting and Finance, 46: 74-83.

Bulut, Ç., Yılmaz, C. \& Alpkan, L. (2009). The effects of market orientation dimensions on firm performance. Ege Academic Review, 9(2), 513-538.

Clark, L.A. \& Watson, D. (1995). Constructing validity: basic issues in objective scale development. Psychological Assessment, 7(3), 309-319.

Cohen, J. (1988). Statistical Power Analysis fort the Behavioral Sciences. Second Edition, Lawrence Erlbaum.

Demirgüneş, K. (2016). The effect of liquidity on financial performance: evidence from Turkish retail industry. International Journal of Economics and Finance, 8(4): 63-79.

Dogan, D. (2019). Data Analysis with SmartPLS (2nd edition). Ankara: ZET Publications.

Ersar1, G. (2018). Strategic Entrepreneurship: The competitive Strategies in the Impact of Entrepreneurial Leadership on Organizational Performance. Unpublished Ph.D. Dissertation, Ataturk University, Erzurum.

Freihat, A.R.F., \& Kanakriyah, R. (2017). Impact of r\&d expenditure on financial performance: Jordanian evidence. European Journal of Business and Management, 9(32): 73-83.

Garson, G. D. (2016). Partial Least Squares: Regression and Structural Equation Models. Asheboro, NC: Statistical Associates Publishers.

Gold, A.H., Malhotra, A. \& Segars, A.H. (2001). Knowledge management: an organizational capabilities perspective. Journal of Management Information Systems, 18(1), 185-214.

Gürbüz, S. (2019). Mediator, Regulatory and Situational Impact Analysis in Social Sciences, Seçkin, Ankara.

Gürbüz, S., Maraşlı, F. \& Costigan, R. (2018). Between personality and emotional commitment exploring the mechanism: the basic self-evaluation and situational of emotional the role of intermediation. 6th organizational behavior congress, 2-3 Kasim, Isparta.

Hair, J. F., Hult, G.T.M., Ringle, C. M., \& Sarstedt, M.; (2014), A Primer on Partial Least Squares Structural Equation Modeling (PLS-SEM), Los Angeles, Second Edition, Sage Publication.

Hair, J.F., Ringle, C.M. \& Sarstedt, M. (2011). PLS-Sem: Indeed a silver bullet. Journal of Marketing Theory and Practice, 19(2), 139-151.

Hayes, A.F. (2018). Introduction to mediation, moderation, and conditional process analysis: A regression-based approach (2nd Edition). New York: The Guilford Press.

Henseler, J., Ringle, C.M. \& Sarstedt, M. (2015). A new criterion for assessing discriminant validity in variancebased structural equation modeling. Journal of the Academy of Marketing Science, 43, 115-135.

Henseler, J., Ringle, C. M., \& Sinkovics, R. R. (2009). The use of partial least squares path modeling in international marketing. In Advances in International Marketing, 20, 277-319.

Işık, N., Engeloğlu, Ö., \& Kılınç, E.C. (2016). The effect of research and development expenditures on the profitability and sales: an application on BIST companies. Journal of Erciyes University Faculty of Economics and Administrative Sciences, 47: 27-46.

Karadeniz, E. \& Kaplan, F. (2016). The effect of capital structure decisions on profitability: a research on Borsa Istanbul tourism companies. Journal of Travel and Hospitality Management 13 (3), 38-55.

Kaya, B. (2007). A Research on Cash Management in Businesses and Industrial and Trade Companies in Bursa. Y1ld1z Technical University Institute of Social Sciences, Master Thesis, Istanbul.

Kim, J. \& Choi, S.O. (2020). A comparative analysis of corporate r\&d capability and innovation: focused on the Korean manufacturing industry. Journal Open Innovation: Technology Market Complexity, 6, 1-20.

Kutlu Furtuna, Ö. (2017). Cash holding level analysis on industrial basis: evidence from listed non-financial firms on Borsa Istanbul. Int. Journal of Management Economics and Business, 13(3), 615-630.

Muller, D., Jud, C.M. \& Yzerbyt, V.Y. (2005). When mediation is moderated and moderation is mediated. Journal of Personality and Social Psychology, 89, 852863.

Mutegi, L.M. (2016). Effects of Capital Structure on the Financial Performance of Firms Listed at the Nairobi Securities Exchange. Unpublished Master's Thesis. University of Nairobi Science in Finance, School of Business, Nairobi. 
MÜSİAD. (2012). Küresel Rekabet İçin AR-GE ve Inovasyon, Stratejik Dönüşüm Önerisi. MÜSİAD Research Reports: 76, Istanbul: Pelikan Printing.

Nunnally, J.C. (1967). Psychometric theory, New York, NY, US: McGraw-Hill.

Otluoğlu, E. (2017). What is Capital Structure? http://emirotluoglu.com/page/2/?wordfence_logHuman =1\&hid=45EA3E484D0A6B1D790E6450EB3F4723(D ate of Access: 18.12.2019).

Oura, M., Zilber, S.N. \& Lopes, E.L. (2016). Innovation capacity, international experience and export performance of SMEs in Brazil. International Business Review, 25, 921-932

Öztürk, E., \& Zeren, F. (2015), The Impact of R\&D expenditure on firm performance in manufacturing industry: further evidence from Turkey. Int.J.Eco. Res., 6(2): 32-36.

Pratheepkanth, P. (2011). Capital structure and financial performance: evidence from selected business companies in Colombo stock exchange Sri Lanka. Journal of Arts, Science \& Commerce, 2(2): 171-183.

Preacher, K.J., Rucker, D.D. \& Hayes, A.F. (2007). Addressing moderated mediation hypotheses: theory, methods and prescriptions. Multivariate Behavioral Research, 42(1), 185-227.

Rocca, M.L., \& Cambrea, D.R. (2018). The effect of cash holdings on firm performance in Large Italian Companies. J. Int. Financ Manage Account, 30: 30-59.

Sarstedt, M., Ringle, C.M., \& Hair, J.F.; (2017), Partial least squares structural equation modeling. Handbook of Market research, 1-40. https://link.springer.com/ referenceworkentry/10.1007\%2F978-3-319-055428_15-1 (Date of Access: 24.12.2019).

Sözüer, A. (2016). Inter-firm Relationship Quality in International Trade: A Study on the Relationships between Exporters in Turkey and their Customers Abroad. Istanbul University Institute of Social Sciences, $\mathrm{PhD}$ Thesis, Istanbul.

Teo, T.S.H., Srivastava, S.C. \& Jiang, L. (2008). Trust and electronic government success: an empirical study. Journal of Management Information Systems, 25(3), 99132.

Topaloğlu, E.E., \& Nur, T. (2016). Effect of cash conversion cycle on the financial performance: a practice on the corporate governance index. Academic Review, 53: 304-317.

Topaloğlu, E.E., Coşkun, N., \& Özkan, C. (2016). Testing the relationship between the ownership structure and financial performance in the Istanbul Stock Exchange
30 Index. Financial, Political \& Economic Commentary, 53(620): 85-107.

Türko, M. (1998), Financial Management. Erzurum: Alfa Publishing House.

Uygurtürk, H., \& Vargün, H. (2018). The Relationship between cash flow and profitability: a research on vehicles sector. Accounting Science World Journal, 20(3): 705-727.

Uzun Kocamış, T., \& Güngör, A. (2014). R\&D expenditure in Turkey and Effect of R\&D expenditure on profitability in technology sector: Borsa Istanbul example. Treasury Magazine, 166: 127-138.

VanderPal, G.A. (2015). Impact of R\&D expenses and corporate financial performance. Journal of Accounting and Finance, 15(7): 135-149.

Venkatraman, N. \& Ramanujam, V. (1986). Measurement of business performance in strategy research: A comparison of approaches. Academy of Management Review, 11(4), 801-814.

Varian, H. (2005). Bootstrap tutorial. The Mathematical Journal, IX(4): 770-771.

Yam, R.C.M., Guan, J.C., Pun, K.F. \& Tang, E.P.Y. (2004). An audit of technological innovation capabilities in chinese firms: some empirical findings in Beijing, China. Research Policy, 33, 1123-1140.

Yener, E., \& Karakuş, R. (2012). Review of relationship between capital structure and firm values in different asset values: an application on Ise 100 firms. Gazi University Journal of Economics and Administrative Sciences, 14(2): 75-98.

Yener, A.L. (2002). The Factors Effecting the Capital Structures of Turkish Firms: An Analysis for the Biggest 500 Firms the Stocks of Which are Traded in the Istanbul Stock Exchange, Ankara University Institute of Social Sciences, PhD Thesis, Ankara.

Yilmaz, H. (2017). The Effect of capital structure on firm value and performance: an empirical analysis. The Journal of International Social Research, 10(53): 826838.

Zehir, C., Can, E. \& Karaboğa, T. (2015). Linking entrepreneurial orientation to firm performance: the role of differentiation strategy and innovation performance. Procedia-Social and Behavioral Sciences, 210, 358367.

Zhu, Z., \& Huang, F. (2012). The effect of R\&D investment on firms' financial performance: evidence from the Chinese listed IT firms. Modern Economy, 3: 915-919. 


\section{Annex-1}

\section{R\&D Capacity}

1. Our company develops technologies by investing in R\&D.

2. Our company acquires new technologies

3. Our company is recognized for its technologically superior products

4. Our company employs some of the most qualified industry experts in the country in product development.

\section{Cash attitude}

1. Liquid Assets / Total Assets

2. Liquid Assets / Net Sales

3. Liquid Assets / Fixed Assets

Capital Structure

1. Long Term Liabilities / Total Assets

2. Short Term Liabilities / Total Assets

3. Total Foreign Resources / Equity

Financial Performance

1. Return on Investment (profit / total assets)

2. Economic Profitability (Profit before interest and tax / total assets)

3. Sales Profitability (profit / net sales)

4. Return on Equity (profit / equity) 